\title{
Stream mouth deposits in the palaeontological site of Somosaguas, Middle Miocene, Madrid Basin
}

\author{
Davinia DÍEZ-CANSECO ${ }^{1, *}$, Nieves LÓPEZ-MARTÍNEZ ${ }^{2, \dagger}$, Margarita DÍAZ-MOLINA ${ }^{1}$ \& \\ $M^{a}$ Isabel BENITO ${ }^{l}$
}

\author{
${ }^{1}$ Dpto. de Estratigrafía. Universidad Complutense de Madrid, IGEO, 28040-Madrid, España; daviniadiezcanseco@pdi.ucm.es; \\ margot@geo.ucm.es; maribel@geo.ucm.es \\ ${ }^{2}$ Dpto. de Paleontología. Universidad Complutense de Madrid, IGEO, 28040-Madrid, España; † Deceased, December 2010 \\ * Corresponding author
}

Díez-Canseco, D., López-Martínez, N., Díaz-Molina, M. \& Benito, Mª I. 2012. Stream mouth deposits in the palaeontological site of Somosaguas, Middle Miocene, Madrid Basin. [Depósitos de desembocadura de canales en el yacimiento paleontológico de Somosaguas, Mioceno medio, Cuenca de Madrid]. Spanish Journal of Palaeontology, 27 (2), 93-104.

\section{ABSTRACT}

The Middle Miocene sediments exposed in Somosaguas contain an excellent record of mammal fossil remains preserved in debris and mudflow deposits. In the sedimentary sequence of Somosaguas three facies associations are distinguished, representing alluvial fan and shallow lake margin environments. Alluvial fans are composed of mud and debris flow deposits. The whole of the lacustrine deposits are interbedded between debris and mud flow deposits. The shallow lake deposits are devoid of fossil remains, and they consist of well-sorted micaceous sandstone bodies with water flow structures, interbedded with thin mudstone beds. These sandstone bodies are interpreted as stream mouth lobes. Three integrated stratigraphic sections show that the lacustrine bedset overlain an erosion surface, probably scoured by flood waters. Palaeocurrent measurements indicate that the sediment filling the shallow lake came from the west and the north.

Keywords: Alluvial fan, shallow lake margin, stream mouth deposits.

\section{RESUMEN}

Los sedimentos miocenos que afloran en Somosaguas contienen un registro excelente de restos fósiles de mamíferos, preservados en depósitos de flujos de fango y de derrubios. En la sucesión sedimentaria de Somosaguas se distinguen tres asociaciones de facies, que representan ambientes de abanico aluvial y de margen de lago somero. Las asociaciones de abanico aluvial están esencialmente compuestas por los depósitos de flujos de fango y de derrubios. El conjunto de los depósitos lacustres está interestratificado entre los depósitos de abanico aluvial, y constituye la asociación de facies objeto de estudio en este trabajo. Esta asociación de facies carece de restos fósiles y consiste en cuerpos de arenisca micácea bien seleccionada, con abundantes estructuras de flujo de agua, intercalados entre capas centimétricas de lutita. Estos cuerpos de arenisca son interpretados como lóbulos de desembocadura de canales. Tres secciones estratigráficas muestran como el conjunto de los depósitos lacustres marginales rellena una topografía probablemente excavada por avenidas. Medidas de paleocorriente indican que el sedimento que rellenó el lago somero procedía del Oeste y del Norte.

Palabras clave: Abanico aluvial, margen de lago somero, lóbulos de desembocadura. 


\section{INTRODUCTION}

The Somosaguas Middle Miocene vertebrate fossil site is located near Pozuelo de Alarcón, within the Somosaguas campus of the Universidad Complutense de Madrid (Fig. 1a). The stratigraphic succession exposed in Somosaguas is $6 \mathrm{~m}$ thick and is partially covered by recent soil and rubble deposits. The study area has an extent of 4,200 $\mathrm{m}^{2}$ (Fig. 1b).

Since the discovering of the first fossil remains in 1989, many authors have contributed to the study of the vertebrate fossils (for example, López-Martínez et al., 2000; Luis \& Hernando, 2000; Cuevas-González, 2005; Hernández-Fernández et al., 2006). As a consequence, 24 species of mammals and various birds and reptiles have been identified in different stratigraphic levels (HernándezFernández et al., 2006; Perales et al., 2009).

The fossil-bearing sediments are matrix-supported conglomerate and pebbly-sandy mudstone, which have been interpreted as debris flow and mudflow deposits of an alluvial fan depositional system (Mínguez-Gandú, 2000). At the middle portion of the stratigraphic succession of the Somosaguas palaeontological site, well-sorted and cross-bedded micaceous sandstone, up to $2 \mathrm{~m}$ thick, is interbedded with thin mudstone beds. No fossil remains have been found in these facies, which have been interpreted as sheet flow deposits (Minguez-Gandú, 2000), or as lacustrine deposits located between alluvial fan sediments (Cuevas-González, 2005).

Palaeoclimatic data provided by the mammalian association indicate tropical conditions with marked seasonality during the Middle Miocene (HernándezFernández et al., 2006). Analyses of clay mineral assemblages in Somosaguas sediments, based on smectite predominance (Fesharaki et al., 2007; Carrasco et al., 2008) have provided palaeoclimatic indications comparable to those previously obtained from the mammalian communities (Hernández-Fernández et al., 2006). Geochemical analyses of fossil dental enamel of herbivore mammals indicate a trend to increasing aridity in the Somosaguas stratigraphic succession (Domingo et al., 2009). Nevertheless, Hernández-Fernández et al. (2006) discussed the climatic significance of the wellsorted micaceous sandstone interbedded and considered it uncertain. a

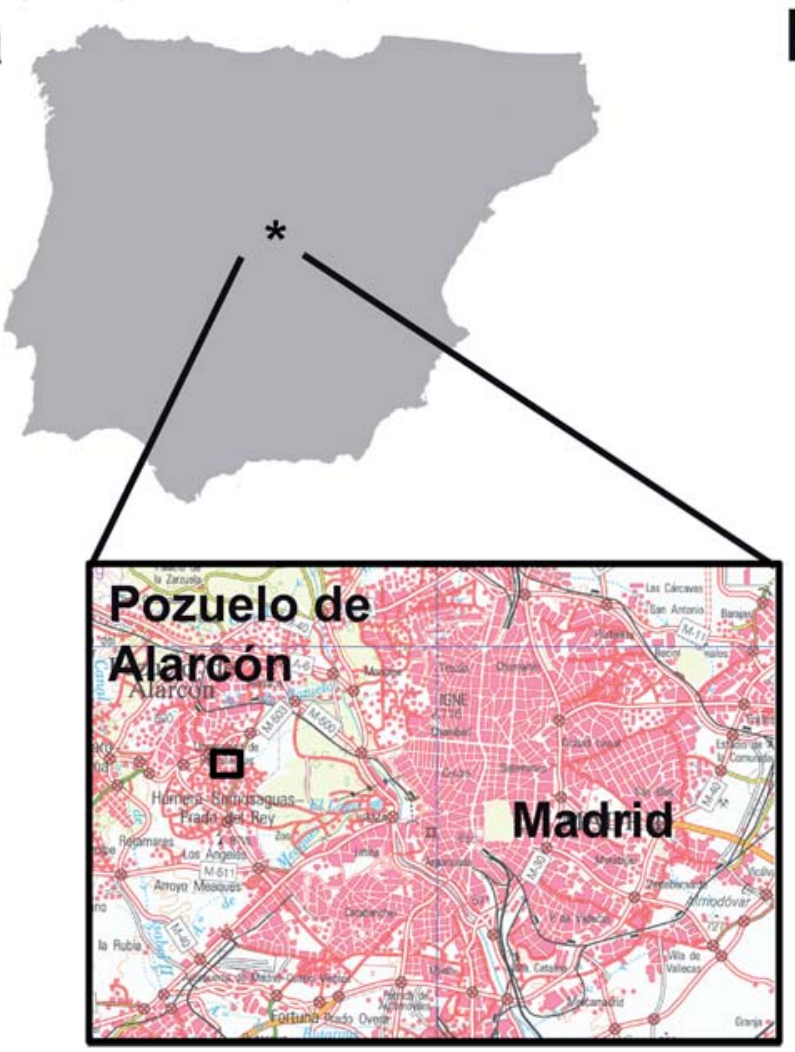

b

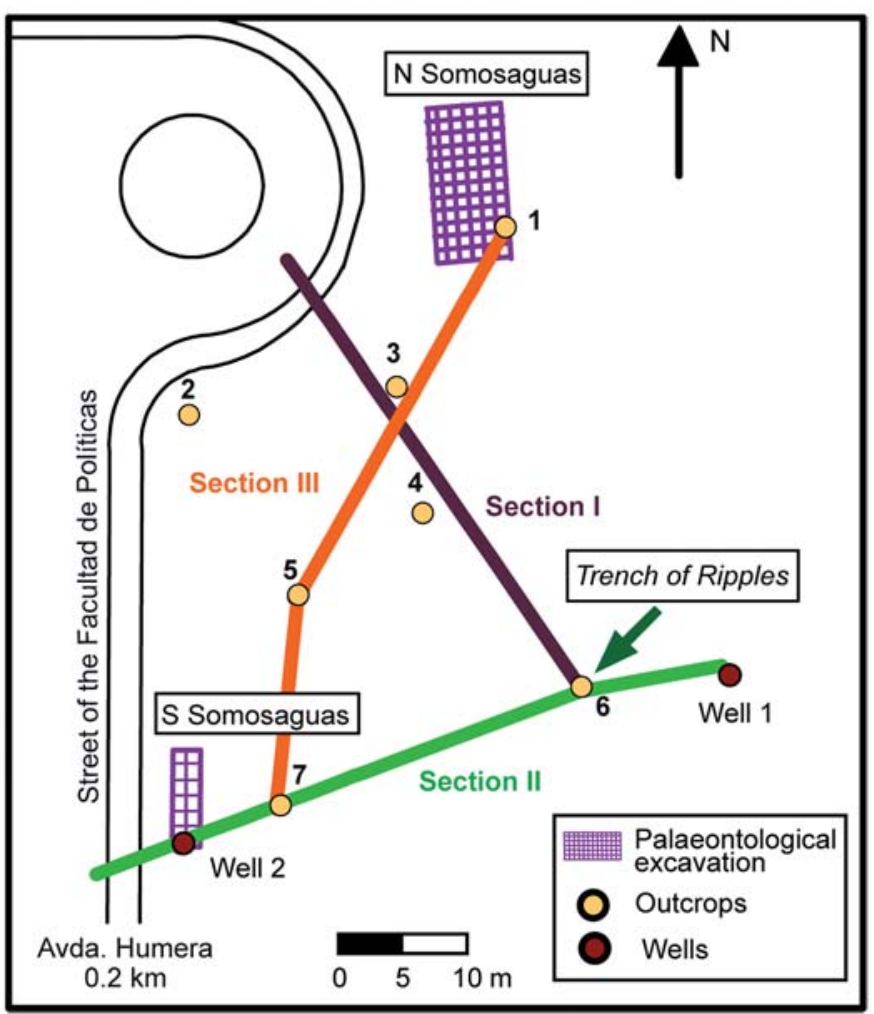

Figure 1. a) Location map of the Somosaguas palaeontological site (Pozuelo de Alarcón, Madrid). b) location of wells and studied outcrops, N and S Somosaguas refer to the two excavation areas (north Somosaguas and south Somosaguas). Colour lines indicate the position of the stratigraphic cross-sections shown in Figure 3. 
In this work we study the well-sorted micaceous sandstone through a detailed logging of the different outcrops (including a $2 \mathrm{~m}$ thick trench) and borehole cores of the Somosaguas palaeontological site (Fig. 1b). Moreover, data are integrated into three stratigraphic crosssections to reconstruct its overall geometry. Our final purpose is to understand the depositional setting of the wellsorted micaceous sandstone and the interbedded mudstone, to interpret their significance on the reconstruction of the local landscape during Middle Miocene time.

\section{GEOLOGICAL SETTING}

The Somosaguas palaeontological site is located to the western Madrid Basin, which is one of the Cenozoic basins in the Iberian Peninsula (Fig. 2a). Most of the outcropping sedimentary filling is of Aragonian age (Peláez-Campomanes et al., 2003; Fig. 2b). The abundant fossil remains found in the Somosaguas palaeontological site (Sps) have been attributed to the E local biozone of Daams et al. (1999) of Middle Aragonian (HernándezFernández et al., 2006).
According to tectonics and sedimentological criteria three stratigraphic units were distinguished in the Miocene of the Madrid Basin: Lower Unit, Intermediate Unit and Upper Unit (Megías et al., 1980; Junco \& Calvo, 1983; Alberdi et al., 1984). During Miocene time, the Madrid Basin was filled by continental sediments, which were classified, from the proximal to the distal areas of the basin, into: a) proximal facies (arkose and conglomerate), b) middle facies (micaceous lutite and arkose), and c) evaporite and lacustrine facies (gypsum and carbonate) (Hoyos et al., 1985; Fig. 2c). The stratigraphic succession of Sps belongs to the Intermediate Unit and is composed of proximal facies (Fig. 2c). Most of the proximal facies are arkosic and matrix-supported and are interpreted as alluvial fan deposits, which source area was located in the Central System (Hoyos et al., 1985). According to the alluvial fan reconstructions (Portero \& Olivé, 1983), the study area would be in the middle-distal zone of these alluvial fan systems.
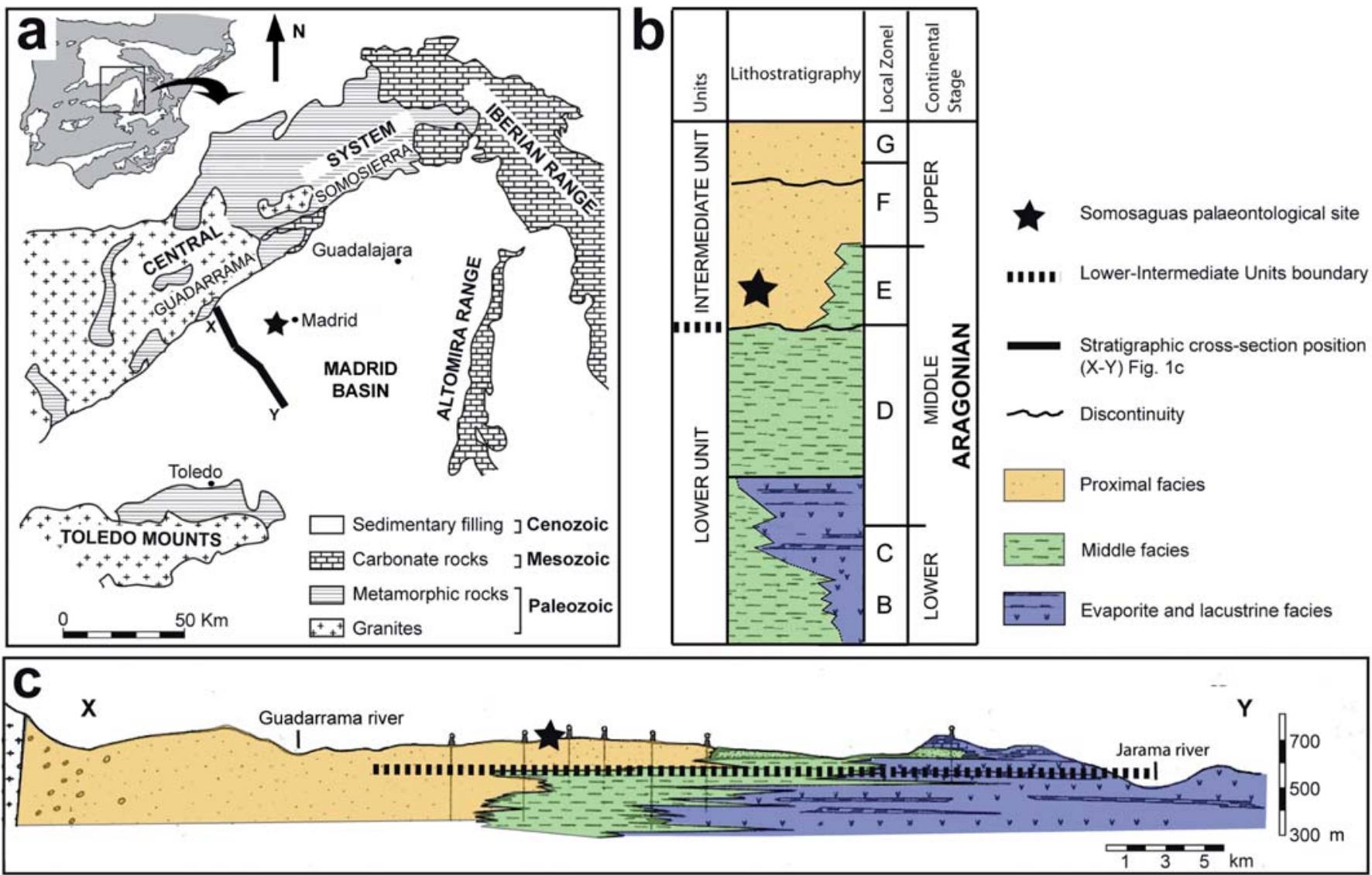

Figure 2. a) Location map of the Somosaguas palaeontological site in the Cenozoic Madrid Basin (Cuevas-González, 2005). b) Synthetic biostratigraphic framework (modified from Peláez-Campomanes et al., 2003) and chronostratigraphic position of the Somosaguas palaeontological site. c) Stratigraphic cross-section of the Madrid Basin showing lateral facies changes (Hoyos et al., 1985). 


\section{STRATIGRAPHY OF THE SOMOSAGUAS PALAEONTOLOGICAL SITE}

The stratigraphic succession of the Sps is divided into six stratigraphic units named from the base to the top as: T-2, T-1, T0, T1, T2 and T3. The lower units (unit $\mathrm{T}-2$, unit $\mathrm{T}-1$ and unit $\mathrm{T} 0$ ) are first defined in this work. The lower units have been described from borehole continuous cores obtained in 2008. The upper units (unit T1, unit T2 and unit T3) crop out along Sps and were described by Minguez-Gandú (2000). Most of the units of Sps correspond to debris flow or mud flow deposits (see chapter 4); only one unit, the unit T2 studied in detail in this work, is formed by well-sorted micaceous sandstone with sedimentary structures left by water flows (see chapter 5). The lithological descriptions of each unit (according to patterns of visual estimation rates, sensu Swanson, 1985) are listed below:

- Unit T-2 is composed of matrix-supported conglomerate. The matrix consists of very fine to medium-grained sand, silt and clay and it comprises up to $75 \%$ of the rock volume. Pebbles are up to $5 \mathrm{~mm}$ size. The content of pebbles increases towards the middle part and the top of the unit. The base of T-2 shows oxidation processes. This unit has been identified in the well 1 (Fig. 3; section II) with a thickness of $175 \mathrm{~cm}$.

- Unit T-1 consists of sandy mudstone. Sand grains (up to $20 \%$ of the rock volume) are more abundant in the lower part of the unit. The unit T-1 is observed in both wells analyzed in this work (Fig. 3; sections II and III). This unit is $45 \mathrm{~cm}$ thick in the well 1 and $50 \mathrm{~cm}$ thick in the well 2 .

- UnitT0 comprisesmatrix-supported conglomerate. The matrix (up to $75 \%$ of the rock volume) consists of very fine to medium-grained sand, silt and clay and the pebbles are up to $5 \mathrm{~mm}$ size. The unit T0 is observed in the well 1 with a thickness of $110 \mathrm{~cm}$ and in the well 2 with a thickness of $150 \mathrm{~cm}$. In the well 1, the conglomeratic deposit is interbedded with a coarse to very coarsegrained sandstone $10 \mathrm{~cm}$ thick (Fig. 3; section II). A fossil remain of a mammal ( $3 \mathrm{~cm}$ size) had been identified in this unit.

- Unit T1 is made up of pebbly and sandy mudstone. The content of coarse- to very coarse-grained sand and pebbles (up to $25 \%$ of the rock volume) decreases toward the top of the unit. Pebbly-sandy mudstone is interbedded with channel-shaped, coarse-grained sandstone levels, up to $1 \mathrm{~cm}$ thick. The unit $\mathrm{T} 1$ crops out partially to the north and west of the Sps, but has not been observed towards the east (Fig. 3). Towards the south of the Sps this unit can be observed completely and its thickness is 57 $\mathrm{cm}$. This unit contains macro and micro-vertebrate remains. The palaeontological excavation area "South Somosaguas" (S Somosaguas; Fig. 1b) is located in this unit (Fig. 3).

- Unit T2 consists of well-sorted micaceous very fine to coarse-grained sandstone interbedded with thin mudstone layers. Sandstone contains abundant tractive sedimentary structures of small and large scale. The unit T2 overlays a concaveshaped erosion surface (Fig. 3; section III) and reach their maximum thickness, $200 \mathrm{~cm}$, to the west of Sps (see $\log 7$ in sections II and III of Figure 3). Our new correlations reveal that unit T2 pinches out eastwards (Fig. 3; section II) as well as to the north where conglomeratic deposits of the unit T3 lie directly over the pebbly-sandy mudstone of the unit T1, as Minguez-Gandú (2000) observed (see log 1 in section III of Figure 3 ). The obtained stratigraphic architecture allows establishing the limits to the north and east of the deposits of the unit T2 (see red dotted line in Figure 3). A detailed description of the unit $\mathrm{T} 2$ is included in chapter 5 .

- UnitT3 comprisesmatrix-supported conglomerate. The matrix (up to $75 \%$ of the rock volume) consists of very fine to coarse-grained sand, silt and clay. The pebbles are up to $10 \mathrm{~cm}$ size althoug the medium size is around $4 \mathrm{~mm}$. Matrixsupported conglomerates are interbedded with channel-shaped, coarse-grained sandstone, up to $5 \mathrm{~cm}$ thick and mudstone layers from 1 to $2 \mathrm{~cm}$ thick. The unit T3 has an erosional basal contact and a maximum thickness of $150 \mathrm{~cm}$ in the north of Sps (Fig. 3; section III). The thickness of the unit T3 decreases slightly to the south of Sps (Fig. 3; sections I and III). The unit T3 is eroded and covered by rubble deposits to the east (Fig. 3; sections I and II). This unit contains abundant vertebrate remains and has been systematically excavated (N Somosaguas; Figs 1b, 3).

\section{SEDIMENTARY FACIES ASSOCIATIONS OF THE SOMOSAGUAS PALAEONTOLOGICAL SITE}

Mínguez-Gandú (2000) interpreted the units T1 and T3 as mud and debris flow deposits respectively. In this work, we analyzed the 6 stratigraphic units described above (T-2, T-1, T0, T1, T2 and T3), which are characterized by three facies associations (FA): FA-1, FA-2 and FA-3 (Figs 3-4). The facies association FA-2 will be analyzed in chapter 5 in detail. 

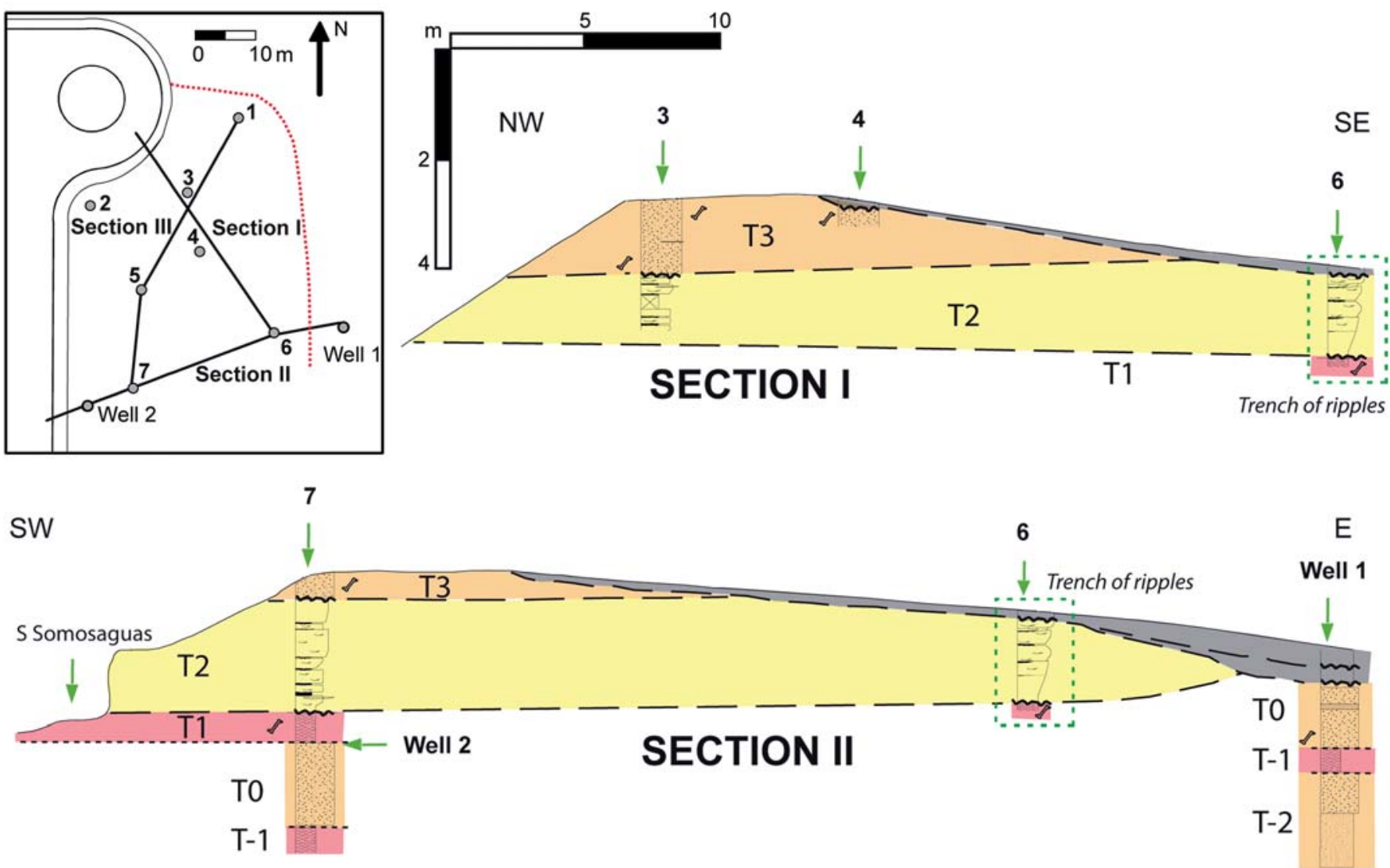

NE

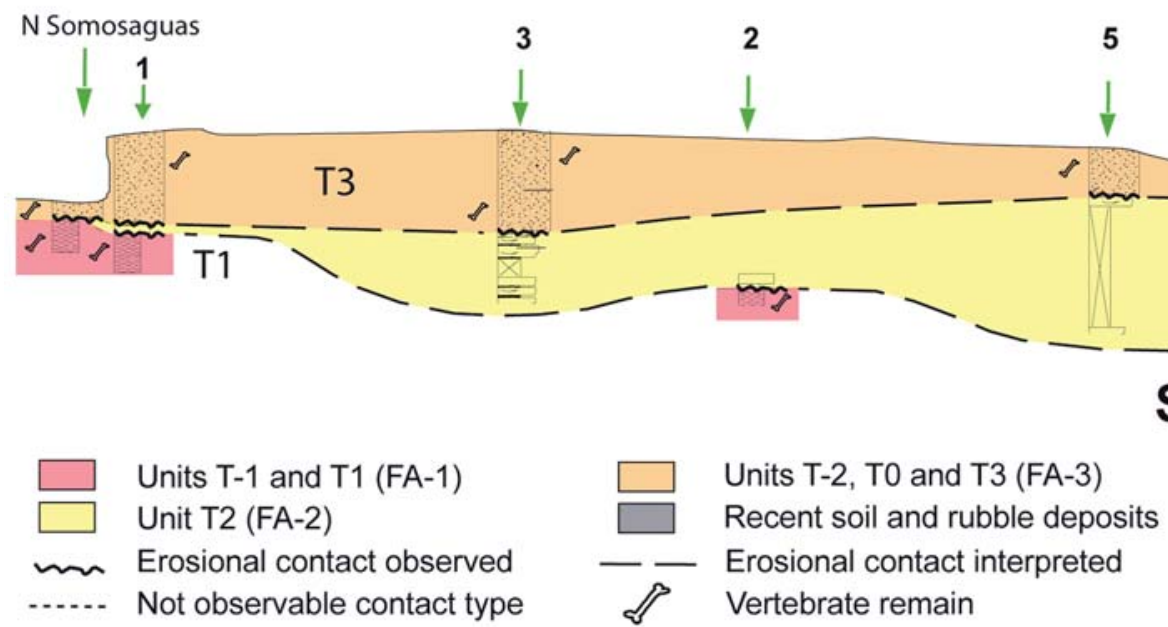

Figure 3. Reconstructed stratigraphic architecture along three cross-sections. Red dotted line indicates the lateral extent of the unit $\mathrm{T} 2$.

FA-1 is observed in units T1 and T-1 (Fig. 4) and corresponds to pebbly and sandy mudstone, which are interpreted as mud flow deposits. FA-3 is found in units T-2, T0 and T3 (Fig. 4) and consist of matrix supported conglomerates, which are interpreted as debris flow deposits. Within the units constituted by FA-1 and FA-3, well-sorted sandstone is found. This sandstone consists of channelized deposits, up to $10 \mathrm{~cm}$ thick, which are interpreted as stream channel fill (Fig. 4).
According to Bull (1972) the bedding of debris flow sequences commonly is not well defined but upon close examination bedding planes between flows can be identified. In fact, in the Somosaguas outcrops, bedding planes can be recognized by the presence of the interbedded channelized deposits. Élez (2005) performed a GIS reconstruction of the layout of 1,300 fossil remains from the unit T3, which showed apparent concentrations of fossil remains. According to Élez (2005) these fossil concentrations allow 


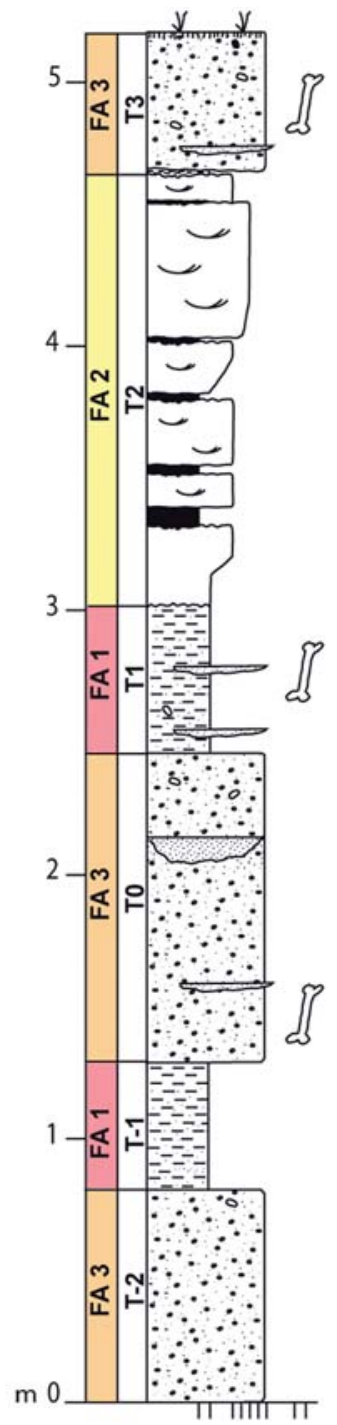

\begin{tabular}{|c|c|c|}
\hline $\begin{array}{c}\text { Facies } \\
\text { Association }\end{array}$ & Facies / Lithology & Interpretation \\
\hline FA-1 & $\begin{array}{l}\text { Massive, pebbly-sandy mudstone with } \\
\text { well-sorted channelized sandstone } \\
\text { Vertebrate fossil-bearing }\end{array}$ & $\begin{array}{l}\text { Mud flows } \\
\text { and small } \\
\text { stream channels }\end{array}$ \\
\hline FA-2 & $\begin{array}{l}\text { Sandstone bodies with enormous } \\
\text { variety of sedimentary structures (see } \\
\text { Fig. 5), which are interbedded with } \\
\text { lens-shaped mudstone or discontinuous } \\
\text { mudstone sheets }\end{array}$ & $\begin{array}{l}\text { Stream mouth } \\
\text { lobes in a shallow } \\
\text { lake margin }\end{array}$ \\
\hline FA-3 & $\begin{array}{l}\text { Massive, matrix-supported conglomera- } \\
\text { te with well-sorted channelized sandsto- } \\
\text { ne } \\
\text { Vertebrate fossil-bearing }\end{array}$ & $\begin{array}{l}\text { Debris flows } \\
\text { and small } \\
\text { stream channels }\end{array}$ \\
\hline \multirow{3}{*}{ 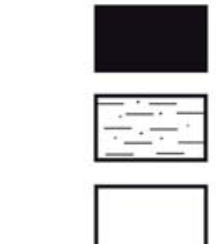 } & Mudstone & Vertebrate fossil \\
\hline & Pebbly-sandy mudstone & Cross-bedding \\
\hline & Micaceous sandstone & Erosional contact \\
\hline \begin{tabular}{lll}
0 & 0 \\
\hdashline & 0 \\
& 0 \\
\end{tabular} & $\begin{array}{l}\text { Matrix-supported conglomerate } \\
\text { Sandstone }\end{array}$ & 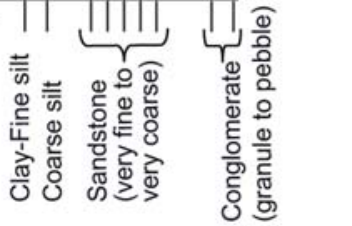 \\
\hline
\end{tabular}

Figure 4. Synthetic stratigraphic log, stratigraphic units and general characteristics and interpretation of facies associations (FA-1, FA-2 and FA-3).

to identify at least 3 superimposed sedimentary bodies. Moreover, some debris flow deposits pass gradually upwards to thin and pure mudstone layers. These mudstone presumably occurred by the vertical transfer of mud, or the elutriation of the finer particles (Schreiber, 1978; Allen, 1982, p. 342) during the debris flow episodes and overlain the matrix-supported deposits.

The presence of fossil remains in debris flow deposits is not common (Bull, 1972), however the Sps is very rich in fossil remains of mammal. Taphonomic studies of fossils of the Sps revealed that many of them are fragile elements and, interestingly, remained intact (Polonio \& López-Martínez, 2000). One similar sedimentological site, where dinosaur fossils were buried by recurrent finegrained debris flow, has been described in the Maeravano Formation of the Upper Cretaceous of Madagascar (Rogers, 2005). As expected, many of the fossils from both sites, Somosaguas and Madagascar, show signs of subaerial exposure before burial, but also show intact remains or bone assemblages with high degree of connexion and preservation of organic tissues. Rogers (2005) suggested that these extraordinary matrix-supported, fossil-bearing deposits shielded vertebrate remains from destructive surfaces.

\section{STREAM MOUTH DEPOSITS IN FA-2: SEDIMENTARY CHARACTERIZATION AND SIGNIFICANCE}

The unit T2 is composed of well-sorted micaceous sandstone of the facies association 2 (FA-2). FA-2 is best exposed in the trench, named the Trench of Ripples (Fig. $1 \mathrm{~b}$ and $\log 6$ 
in Figure 3), which allows a three-dimensional observation of deposits (Fig. 5). A sharp contact between units T1 and T2 is observed at the bottom of the Trench of Ripples. The contact between units T2 and T3 is not observable because in the upper part of the trench, the stratigraphic succesion is eroded and covered by rubble deposits (Fig. 5). The unit T2 is composed of interbedded well-sorted sandstone and mudstone and is slightly coarsening-upwards. Sandstone is greyish, micaceous and contains tractive sedimentary structures (Figs 5a-5b). Sandstone beds form wedge and plane-convex shaped bodies whose thicknesses vary between 20 and $40 \mathrm{~cm}$. Mudstone beds are thin, up to $10 \mathrm{~cm}$ thick, are delimited by irregular surfaces and have been partially eroded (Figs 5a-5b, 5d). Unit T2 is devoid of fossil content throughout the Sps.

A noticeable feature of T2 at the Trench of Ripples is the presence of a network of sub-horizontal layers and thin vertical structures filled with white carbonate widespread throughout the trench (Fig. 5a). Sub-horizontal layers are parallel to the bedding and are situated between sedimentary bodies of different permeability; specifically carbonates precipitated above mudstone bodies and below sandstone bodies (Fig. 5a). Vertical structures reach the upper part of the trench and connected several sub-horizontal layers (Fig. 5a). Carbonates precipitated in horizontally and vertically horizons, showing identical macroscopic and microscopic features, consisting of homogeneous and peloidal micrite. These observations suggest that carbonate precipitated at the same time in both cases, probably associated with relatively recent paleosols development.

The sandstone bodies ( $\mathrm{Sb}$ in Figure 5) of unit T2 are very fine- to coarse-grained. The sandstone bodies show large and small-scale cross-bedding, climbing ripples cross-bedding, parallel lamination, and foreset laminae or bar cross-bedding. Five sandstone bodies ( $\mathrm{Sb} 1$ to 5 ) are distinguished (Figs 5a-5b), which have irregular basal contacts due to erosion. Most of the sandstone bodies show coarsening upward sequences (Fig. 5b). Sedimentary structures are not identifiable within the deposits of $\mathrm{Sb} 1$, though some small-scale laminae are recognizable. The deposits of $\mathrm{Sb} 2$ are constituted by the superposition of several cosets of climbing ripple cross-bedding (Fig. 5c). The most complex deposits are those of $\mathrm{Sb} \mathrm{3,} \mathrm{which} \mathrm{has}$ a coarsening-fining trend. The coarsening upward lower portion consists of a coset of small-scale cross-bedding, which is slightly eroded at the top. The scouring of the bed allowed the development of a small bar (Fig. 5d) formed by flow expansion because of the pre-existing topography (Cant, 1978). The upper portion of the Sb 3 shows parallel lamination followed of small-scale cross-bedding, due to the waning stage of the flow (Fig. 5d). Two cosets of small-scale structures are identified in the deposits of $\mathrm{Sb} 4$, a coset of climbing ripple cross-bedding overlaid by other of small-scale trough cross-bedding. The deposits of $\mathrm{Sb}$ 5 consist of a coset of small-scale trough cross-bedding followed by a coset of large-scale trough cross-bedding (Fig. 5e). A synthesis of T2 facies is shown in Figure 5.

These five sandstone bodies are identified as non channelized deposits. Their association with muddy beds involves a sedimentary environment with a stagnant mass of water. The deposits of the unit T2 are interpreted to represent stream mouth lobes or terminal splays (sensu Fisher et al., 2008) of stream or sheet flow sediments concentrated downslope into swales or small channels (Committee on Alluvial Fan Flooding, 1996) and trapped in a topographic depression, which origin is discussed below. The real size of the topographic depression is unknown but according to our reconstruction the minimum area of the depression is about $900 \mathrm{~m}^{2}$ (Fig. 3), which would be between the dimension of a pond and a lake (sensu González Bernáldez, 1992). The coarsening sequences in sandstone bodies 1, 2, 4 and 5 are related to the growing and progradation of single lobes (Fig. 6a), while the coarsening-fining upwards trend in $\mathrm{Sb} 3$, containing internal erosion surface, could represent the superposition of two stream mouth lobes.

Palaeocurrents directions are $\mathrm{N} 90^{\circ} \mathrm{E}$, in sandstone bodies $1,2,3$ and 4 , and $\mathrm{N} 180^{\circ} \mathrm{E}$ in $\mathrm{Sb} 5$. This palaeocurrent dispersion involves a change in sediment inputs, probably due to channel avulsion. Lateral avulsion is a common process occurring in sands discharges into a shallow mass of water because of the limited accommodation space that provides coastal morphology (Fregenal-Martínez \& Meléndez, 2010).

The sandstone bodies show narrow and shallow incisions at the top, probably produced by incision of rills during base level fall (Fig. 6). The interbedded mudstone could represent the settling of finer sediment associated to lateral fining and thinning of other lobes, laterally deposited.

Similar facies to those of the unit T2 have been described by Fregenal-Martínez \& Meléndez (2010) as deposited in fluvial domain deltas of lakes with low gradient littoral zone. These facies are characterized by coarsening upward sequences of lens-shaped sandstone bodies with tractive current structures, which commonly are interbedded with fine deposits. Moreover, according to Fregenal-Martínez \& Meléndez (2010) multiple lobes are favoured by shallow water and very low gradient borders. Also, T2 deposits are similar to the lobate mouth bars described by Turner \& Tester (2006) in the Westphalian B Coal Measures of the NE of England, which were deposited in an interdistributary lake by frequent crevassing from the feeder channel. Other similar deposits are found in the modern mouth of Douglas Creek in the Lake Eyre, central Australia, where distributary channels feed sediment lobes, which form a terminal splay (Fisher et al., 2008). Terminal splay is defined by these authors as "a lobe-shaped body of sediment found at the terminus of a river that has been deposited from unconfined, sub-aerial sheet-floods which 

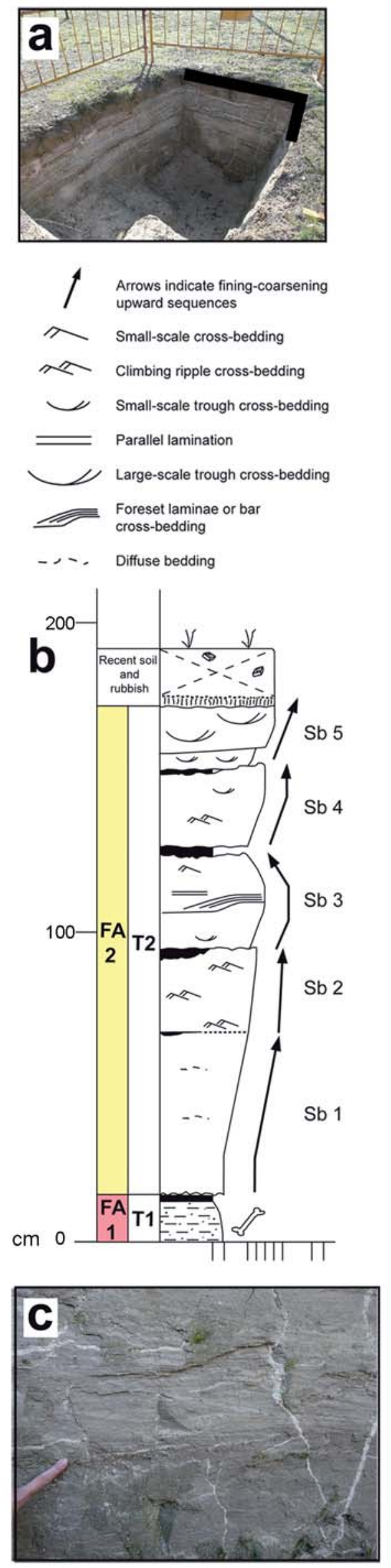
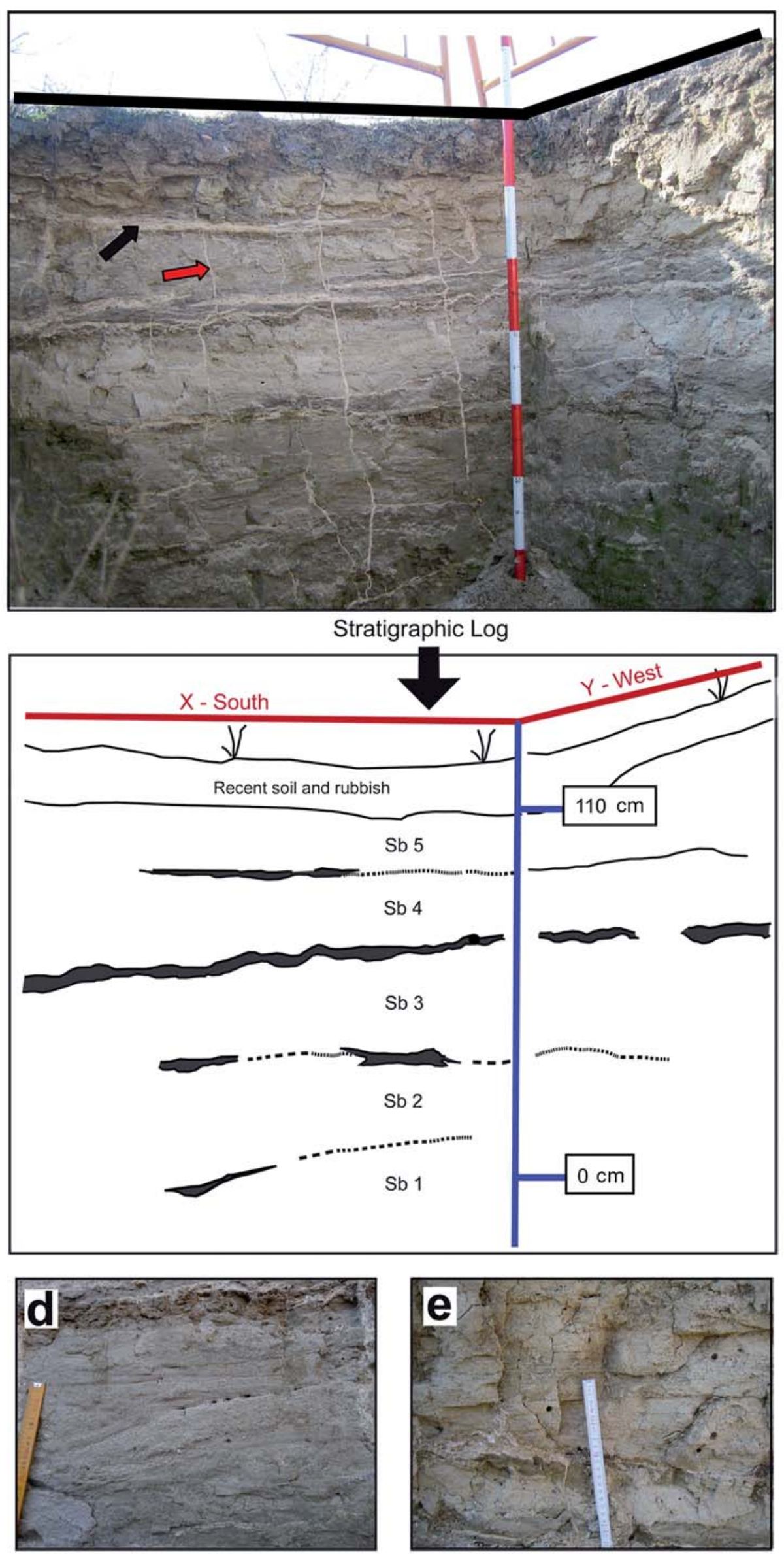
propagated over a dry flood-plain, playa or lake bed" (Fisher et al., 2008; p. 1916). The common feature in all the cases is that the sediment download is produced in a topographic depression with low gradient borders. The lack of fossil remains in the well-sorted facies of the unit T2 (FA-2) could be explained in terms of this different sedimentary environment. The vertebrate remains possibly left by currents in the topographic depressions would not have been rapidly buried and shielded, in contrast to those deposited within the debris and mud flow deposits, being thus affected by weathering processes.

Cuevas-González (2005) proposed that deposits of the unit T2 could be located between not coalescent alluvial fans. Nevertheless, the reconstruction of the volume of this unit shows that the topographic depression could have been originated by the combination of erosion during a flooding and the subsequent construction of a barrier that impounded the water and sediments. The damming had to have been produced by sediments of the own fan; thus the pond or shallow lake was probably originated by the autocyclic control of the alluvial fan system.

In the Madrid Basin, interbedded mudstone and sheets of micaceous sandstone are observed in the most distal facies of the alluvial fans coming from the Central System (midle facies in Fig. 2) and comprises the "Unidad de Alcalá" (Aznar Aguilera \& Pérez González, 1990; Portero García \& Pérez González, 1990). The sandstone is finer grained than that of the unit T2, and shows fining upward sequences. These sandstone sheets were interpreted as stream mouth deposits (Aznar Aguilera \& Pérez González, 1990; Portero García \& Pérez González, 1990). However, in accordance with palaeogeographic reconstructions of

\section{a}

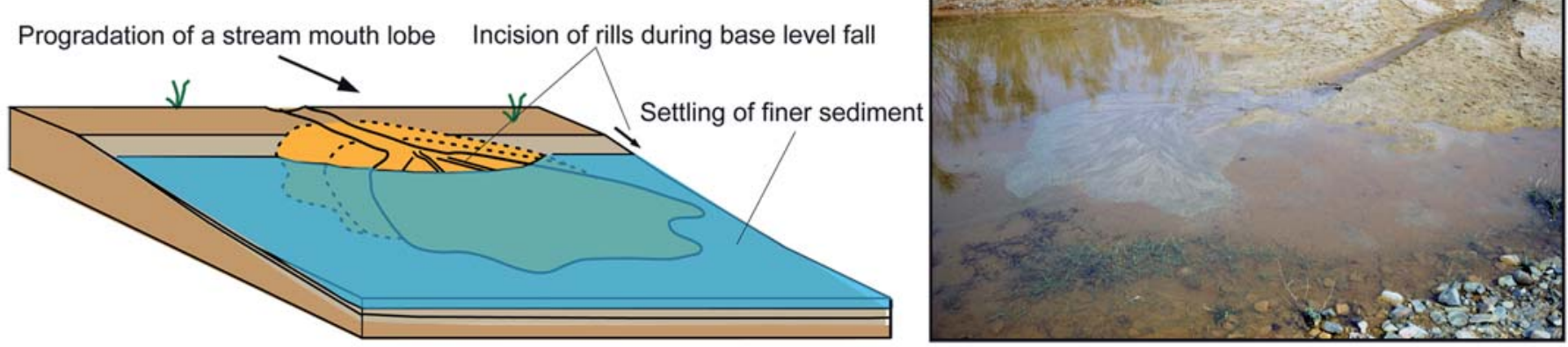

Figure 6. Progadation of stream mouth lobes. a) A prograding lobe showing partial emersion and rill incisions. b) Recent analogue showing two stream mouth lobes in an ephemeral pond, one of them is fully emerged and partially eroded by rill incisions and the other growing, formed after a base level fall. Sandy lobe deposits pass laterally to finer sediments.

the Middle Miocene of Madrid Basin (Portero \& Olivé, 1983; Hoyos et al., 1985) the stratigraphic section of Sps would not represent the distal facies of the alluvial fan but the transition between middle to distal fan deposits (see Fig. 2c); in fact deposits of unit T2 are coarser grained with dominance of coarsening upward sequences; and are interbedded between mud and debris flow deposits.

The studied Somosaguas section represents deposits of an alluvial fan though the section is too thin to accomplish a sedimentological study of the alluvial fan deposits. The association of stream flow and debris flow deposits is characteristic of composite fans, fed by both water flows and debris flows, but stream flows also occur in, the most arid, debris flow fans (Committee on Alluvial Fan Flooding, 1996). Therefore the facies associations found in the Sps would be probably controlled by autocyclic processes and might represent any of the two types of fans, not providing any evidence of climate change.

Figure 5. Sedimentary facies in the Trench of Ripples. a) Trench of Ripples, showing well-sorted micaceous sandstone with interbedded mudstone and the network of vertical structures (red arrow) and horizontal layers (black arrow) of white carbonate. Note the irregular lateral continuity of mudstone deposits. b) Stratigraphic section and schematic sketch of the trench walls, mudstone facies (black) and sandstone bodies ( $\mathrm{Sb}$ ). c) Two sets of climbing ripple cross-bedding in Sb 2. d) Bar crossbedding covered by parallel lamination in Sb 3 and overlying mudstone layer. e) Large-scale trough cross-bedding within $\mathrm{Sb} 5$. 


\section{CONCLUDING REMARKS}

The stratigraphic succession of the Somosaguas palaeontological site is composed of 6 units (T-2, T-1, T0, $\mathrm{T} 1, \mathrm{~T} 2$ and $\mathrm{T} 3$ ), three of them (T-2, T-1 and T0) defined in this work for the first time. These units are characterized by three facies associations, FA-1, FA-2 and FA-3. FA-1 is found in $\mathrm{T}-1$ and $\mathrm{T} 1$ and is dominated by mud flow deposits. FA-3 is found in $\mathrm{T}-2, \mathrm{~T} 0$ and $\mathrm{T} 3$ and is made up mainly of debris flow deposits. FA-2 characterizes the unit T2 and consists of well-sorted sandstone bodies interbedded with thin mudstone layers and is interpreted as stream mouth lobes deposits left in a pond or shallow lake originated by the combination of erosion during a flooding and the subsequent construction of a barrier that impounded the water and sediments.

The association of stream flow and debris flow deposits observed in the Sps is characteristic of both composite and debris flow fans and could be produced as a consequence of autocyclic processes, not providing clear evidence of climate change.

\section{ACKNOWLEDGEMENTS}

This research was supported by the Ministerio de Ciencia e Innovación of Spain (Proyect CGL2009-09000 and a FPI predoctoral contract). We wish to thank Rudnik Ciencias de la Tierra, S.L. by the wells made in the fossil site and Somosaguas Paleontology Project team (http:// www.ucm.es/info/somosagu/) for their help, particularly M. Hernández-Fernández. We also thank J. Cuevas González (Universidad de Alicante) and J. Élez for the stimulating discussions and for their critical comments. This work is a contribution from the research groups UCM-CAM 910198 on Paleoclimatología y Cambio Global, and UCM-CAM 910429 on Análisis de Cuencas Sedimentarias. Finally, we acknowledge editors, reviewer Manuel Pozo (Universidad Autónoma de Madrid) and an anonymous reviewer for their useful comments and suggestions that helped to greatly improve the final version of this manuscript.

\section{REFERENCES}

Alberdi, M.T., Hoyos, M., Junco, F., Lopez-Martínez, N., Morales, J., Sese, C. \& Soria, D. 1984. Biostratigraphy and sedimentary evolution of continental Neogene in the Madrid basin. Paléobiologie Continentale, 2, 47-68.

Allen, J.R.L. (ed.) 1982. Sedimentary Structures: Their Character and Physical Basis. Volume II. Elsevier Scientific Publishing Company, USA.

Aznar Aguilera, J.M. \& Pérez González, A. 1990. Hoja Geológica $n^{\circ} 535$ (Algete). Mapa Geológico de España a escala 1:50.000, $2^{a}$ serie (MAGNA). Instituto Geológico y Minero de España, Madrid.

Bull, W.B. 1972. Recognition of alluvial fan deposits in the stratigraphic record. In: Recognition of Ancient Sedimentary Environments (eds. Rigby, J.K. \& Hamblin, W.K.). Society of Economic Paleontologists and Mineralogists, Special Publication, 16, 63-83.

Cant, D.J. 1978. Bedforms and bar types in the south Saskatchewan River. Journal of Sedimentary Petrology, 48, 1321-1330.

Carrasco, A., Sacristán, S., Benítez-López, G., RomeroNieto, D., Fesharaki, O. \& López-Martínez, N. 2008. Aplicaciones paleoclimáticas y paleoambientales de los estudios mineralógicos al yacimiento de vertebrados miocenos de Somosaguas. Seminario de Paleontología de Zaragoza, 8, 135-149.

Committee on Alluvial Fan Flooding, National Research Council. 1996. Alluvial Fan Flooding. National Academies Press, USA.

Cuevas-González, J. 2005. Estado actual de los conocimientos paleontológicos y estratigráficos de los yacimientos aragonienses de Somosaguas (Pozuelo de Alarcón, Madrid). Coloquios de Paleontología, 55, 103-124.

Daams, R., Peláez-Campomanes, P., Álvarez-Sierra, M. \& Van Der Meulen, A.J. 1999. Aragonian stratigraphy reconsidered, and re-evaluation of the Middle Miocene mammal biochronology in Europe. Earth and Planetary Science Letters, 165, 287-294.

Domingo, L., Cuevas-González, J., Grimes, S.T., HernándezFernández, M. \& López-Martínez, N. 2009. Multiproxy reconstruction of the palaeoclimate and palaeoenvironment of the Middle Miocene Somosaguas site (Madrid, Spain) using herbivore dental enamel. Palaeogeography, Palaeoclimatology, Palaeoecology, 272, 53-68.

Élez, J. 2005. Aplicación GIS 3D a los yacimientos paleontológicos de Somosaguas. DEA, Universidad Complutense de Madrid (unpublished).

Fesharaki, O., García-Romero, E., Cuevas-González, J. \& López-Martínez, N. 2007. Clay mineral genesis and chemical evolution in the Miocene sediments of Somosaguas, Madrid basin, Spain. Clay Minerals, 42, 187-201.

Fisher, J.A., Krapf, C.B.E., Lang, S.C., Nichols, G.J. \& Payenberg, T.H.D. 2008. Sedimentology and architecture of the Douglas Creek terminal splay, Lake Eyre, central Australia. Sedimentology, 55, 1915-1930.

Fregenal-Martínez, M.A. \& Meléndez, N. 2010. Lagos y sistemas lacustres. In: Sedimentología: Del Proceso Físico a la Cuenca Sedimentaria (ed. Arche, A.). Consejo Superior de Investigaciones Científicas (CSIC), Madrid, 299-396.

González Bernáldez, F. 1992. Los Paisajes del Agua: Terminología Popular de los Humedales. Asociación Española de Limnología, Valencia.

Hernández-Fernández, M., Cárdaba, J.A., Cuevas-González, J., Fesharaki, O., Salesa, M.J., Corrales, B., Domingo, L., Élez, J., López Guerrero, P., Sala-Burgos, N., Morales, J. \& López-Martínez, N. 2006. Los yacimientos de 
vertebrados del Mioceno medio de Somosaguas (Pozuelo de Alarcón, Madrid): Implicaciones paleoambientales y paleoclimáticas. Estudios Geológicos, 62, 263-294.

Hoyos, M., Junco, F., Plaza, J.M., Ramírez, A. \& Ruiz Sánchez-Porro, J. 1985. El Mioceno de Madrid. In: Geología y Paleontología del Terciario Continental de la Provincia de Madrid (Alberdi, M.T.). Museo Nacional de Ciencias Naturales-CSIC, Madrid, 9-16.

Junco, F. \& Calvo, J.P. 1983. Cuenca de Madrid. In: Libro Jubilar J. M. Ríos: Geología de España. Instituto Geológico y Minero de España, Madrid, 534-542.

López-Martínez, N., Élez, J., Hernando, J.M., Luis, A., Mazo, A., Mínguez-Gandú, D., Morales, J., Polonio, I., Salesa, M.J. \& Sánchez, I. 2000. Los vertebrados fósiles de Somosaguas (Pozuelo, Madrid). Coloquios de Paleontología, 51, 69-86.

Luis, A. \& Hernando, J.M. 2000. Los microvertebrados fósiles del Mioceno Medio de Somosaguas Sur (Pozuelo de Alarcón, Madrid, España). Coloquios de Paleontología, 51, 87-136.

Megías, A.G., Ordóñez, S. \& Calvo, J.P. 1980. Rupturas sedimentarias en series continentales. Aplicación a la cuenca de Madrid. IX Congreso Nacional de Sedimentología, Abstract Book, 2, p. 666-680.

Mínguez-Gandú, D. 2000. Marco estratigráfico y sedimentológico de los yacimientos paleontológicos miocenos de Somosaguas (Madrid, España). Coloquios de Paleontología, 51, 235-266.

Peláez-Campomanes, P., Morales, J., Álvarez Sierra, M.A., Azanza, B., Fraile, S., García Paredes, I., Hernández Fernández, M., Herráez, E., Nieto, M., Pérez, B., Quiralte, V., Salesa, M.J., Sánchez, I.M. \& Soria, D. 2003. Updated biochronology of the Miocene mammal faunas from the
Madrid basin (Spain). In: Distribution and Migration of Tertiary Mammals in Eurasia. A Volume in Honour of Hans de Bruijn (eds. Reumer, J.W.F. \& Wessels, W.). Deinsea, 10, 431-441.

Perales, R., Serrano, H., García Yelo, B.A. \& HernándezFernández, M. 2009. Inferencias paleoambientales del Mioceno medio de Somosaguas (Pozuelo de Alarcón, Madrid) basadas en la estructura de tamaños corporales de su fauna de mamíferos. Paleolusitana, 1, 317-325.

Polonio, I. \& López-Martínez, N. 2000. Análisis tafonómico de los yacimientos de Somosaguas (Mioceno Medio, Madrid). Coloquios de Paleontología, 51, 235-266.

Portero, J.M. \& Olivé, A. 1983. El terciario del borde meridional de Guadarrama y Somosierra. In: Libro Jubilar J. M. Ríos: Geología de España. Instituto Geológico y Minero de España, Madrid, 527-534.

Portero García, J.M. \& Pérez González, A. 1990. Hoja Geológica $n^{\circ} 560$ (Alcalá de Henares). Mapa Geológico de España a escala 1:50.000, $2^{\text {a }}$ serie (MAGNA). Instituto Geológico y Minero de España, Madrid.

Rogers, R.R. 2005. Fine-gravel debris flows and extraordinary vertebrate burials in the Late Cretaceous of Madagascar. Geology, 33, 297-300.

Schreiber, B.C. 1978. Elutriation. In: The Encyclopedia of Sedimentology (eds. Fairbridge, R.W. \& Bourgeois, J.). Dowden, Hutchinson \& Ross, Inc., USA.

Swanson, R.G. 1985. Sample Examination Manual. Methods in Exploration Series. The American Association of Petroleum Geologists, USA.

Turner, B.R. \& Tester, G.N. 2006. The Table Rocks Sandstone: A fluvial, friction-dominated lobate mouth bar sandbody in the Westphalian B Coal Measures, NE England. Sedimentary Geology, 190, 97-119. 
